\title{
ETNISITAS DAN KONSERVATISME AKUNTANSI PADA PERUSAHAAN PUBLIK DI INDONESIA
}

\author{
Antonius Singgih Setiawan $^{1}$, Ellen Fransysca ${ }^{2}$ \\ ${ }^{1,2}$ Fakultas Bisnis Akuntansi Universitas Katolik Musi Charitas \\ singgih@ukmc.ac.id
}

\begin{abstract}
Accounting conservatism is debated in practice, literature, and financial accounting research. The principle of conservative accounting is considered as an action to control the optimistic behavior of management and business owners but the potential to cause biased information. This study aims to examine the influence of ethnicity of authorized officials in the publication of corporate financial statements on accounting conservatism in public companies in Indonesia. A total of 71 samples of manufacturing companies listed on the IDX in 2019 and fulfilling sampling criteria were used to test the hypothesis. The research data were analyzed using independent sample t-test. The results showed that the difference in the ethnicity of the official level in the company's financial reporting would affect the level of accounting conservatism in a company. Pribumi ethnicities with general characteristics as ethnicities that prioritize stability in their business tend to have higher conservatism characteristics compared to Tionghoa ethnic groups who tend to be more willing to take risks in their every decision. An important implication of the results of this study is that the authorized officials in publishing the company's financial statements must be able to control their conservative principles.

Keywords: Accounting conservatism; Ethnicity; Manufacturing sector; Pribumi ethnic; Tionghoa ethnic
\end{abstract}

\section{Abstrak}

Konservatisme akuntansi menjadi perdebatan dalam praktik, literatur dan penelitian akuntansi keuangan. Prinsip konservatisme akuntansi dinilai sebagai tindakan untuk mengendalikan perilaku optimistis manajemen dan pemilik usaha namun berpotensi menimbulkan informasi yang bias. Penelitian ini bertujuan untuk menguji pengaruh etnisitas pejabat yang berwenang dalam pemublikasian laporan keuangan perusahaan terhadap konservatisme akuntansi pada perusahaan publik di Indonesia. Sebanyak 71 sampel perusahaan manufaktur yang terdaftar di BEI tahun 2019 dan memenuhi kreteria sampling digunakan untuk menguji hipotesis. Data penelitian di analisis menggunakan independent sample t-test. Hasil penelitian menunjukkan bahwa perbedaan kelompok etnisitas pejabat yang berwenang dalam pelaporan keuangan perusahaan akan berpengaruh pada tingkat konservatisme akuntansi di suatu perusahaan. Etnis Pribumi dengan karakteristik umum sebagai etnis yang lebih mengedepankan sifat stabil dalam berusaha cenderung memiliki sifat konservatisme yang lebih tinggi dibandingkan dengan kelompok etnis Tionghoa yang cenderung lebih berani ambil risiko pada setiap keputusan mereka. Implikasi penting dari hasil penelitian ini adalah para pejabat yang berwenang dalam pemublikasian laporan keuangan perusahaan harus dapat mengendalikan prinsip konservatime mereka.

Kata Kunci: Etnisitas; Etnis Pribumi; Etnis Tionghoa; Konservatisme akuntansi; Sektor manufaktur

Cronicle of Article: Received (September 2020); Revised (October 2020); and Published (December 2020).

C2020 Jurnal Kajian Akuntansi Lembaga Penelitian Universitas Swadaya Gunung Jati.

Profile and corresponding author: Antonius Singgih Setiawan and Ellen Fransysca are from Faculty of Accounting and Business, Universitas Katolik Musi Charitas. Corresponding Author: singgih@ukmc.ac.id

How to cite this article: Setiawan, A. S. \& Fransysca, E. (2020). Etnisitas dan Konservatisme Akuntansi pada Perusahaan Publik di Indonesia. Jurnal Kajian Akuntansi. 4 (2), 170-183. 


\section{PENDAHULUAN}

Konservatisme akuntansi merupakan salah prinsip yang sering dipraktikkan manajemen perusahaan dalam aktivitas pelaporan keuangan (Deslatu \& Susanto, 2010). Konservatisme akuntansi merupakan prinsip kehati-hatian dalam pelaporan keuangan ketika perusahaan menghadapi lingkungan ekonomi dan bisnis yang tidak pasti (Rahmadhani \& Nur, 2015; Sugiarto \& Fachrurrozie, 2018; Suharni et al., 2019). Namun demikian, konservatisme akuntansi merupakan konsep yang dianggap kontroversial dan menjadi perdebatan dalam literatur dan penelitian akuntansi (Wijaya, 2012; Salehi \& Sehat, 2018).

Perilaku konservatif yang dipilih oleh para penentu kebijakan perusahaan tidak terlepas dari perkembangan bisnis global yang penuh dengan ketidakpastian. Jika dilihat pada perkembangan bisnis kini, perang dagang yang terjadi dan dilakukan oleh negara-negara maju seperti Amerika dan China semakin mendorong para pengusaha untuk lebih berhati-hati dalam mengambil keputusan bisnis. Hal ini merupakan salah satu bentuk pemikiran konservatif dalam membuat keputusan bisnis. Perilaku ini pada akhirnya juga berdampak pada keputusan untuk segera melakukan atau menunda pengakuan sebuah transaksi dalam pelaporan akuntansi mereka.

Pada satu sisi, konservatisme akuntansi dipandang bermanfaat untuk mengantisipasi ketidakpastian, namun, konservatisme akuntansi dianggap tidak mencerminkan kondisi keuangan perusahaan yang sebenarnya (Sulastri \& Anna, 2018). Implikasi dari penerapan prinsip konservatisme akuntansi adalah pilihan metode akuntansi yang ditujukan pada pengakuan kerugian yang belum terealisasi dan menunda pengakuan keuntungan sampai benar-benar terealisasi (Sun \& Liu, 2011). Sebagai dampak dari penerapan prinsip konservatisme akuntansi, laporan keuangan menjadi konservatif dan berpotensi menjadi bias sehingga tidak sesuai dengan realitas (Novitasari et al., 2020).

Pada sisi lain, ada pandangan yang menyatakan bahwa kinerja di bawah konservatisme akuntansi bisa mengurangi konflik antara pemegang saham dan eksekutif karena konservatisme akuntansi dapat membantu membatasi peluang manajemen untuk tindakan yang tidak efisien (Zhang et al., 2019). Konservatisme akuntansi juga dipandang dapat mengurangi biaya agensi (Xu et al., 2012). Konservatisme akuntansi merupakan fitur pengukuran akuntansi, dan membatasi perilaku oportunistik manajerial sehingga berperan dalam meningkatkan keandalan pelaporan dan pengungkapan keuangan (Kung et al., 2008). Penerapan konservatisme dalam akuntansi juga bertujuan untuk mengurangi besarnya biaya politis seperti pajak (Suharni et al., 2019).

Konservatisme akuntansi juga dinyakini dapat meningkatkan efisiensi investasi dengan melakukan mitigasi pada investasi yang memiliki risiko. Produk akuntansi berupa pelaporan keuangan yang lebih konservatif akan mengarahkan pada risiko yang lebih rendah atas keputusan investasi atau pendanaan yang dilakukan perusahaan (Kravet, 2014). Hal ini didukung oleh (Zhong \& Li, 2016) yang menyatakan bahwa praktik konservatisme akuntansi yang diterapkan manajemen akan meningkatkan efisiensi dan pengurangan risiko pada keputusan investasi yang telah dikerjakan.

Beberapa perdebatan tentang praktik konservatisme akuntansi tersebut telah membawa perkembangan dalam literatur dan penelitian. Terlepas dari manfaat positif atau dampak negatif dari praktik konservatisme akuntansi, para peneliti terdahulu telah megidentifikasi faktorfaktor yang diprediksi menjadi pendorong praktik konservatisme akuntansi yang 
dilakukan oleh manajemen perusahaan. Isu kinerja keuangan telah menjadi faktor umum yang dilihat oleh para peneliti. Hal tersebut antara lain adalah leverage, financial distress dan profitabilitas (Susanto \& Ramadhani, 2016; Abdurrahman \& Ermawati, 2018), biaya modal (Chan et al., 2009).

Beberapa peneliti juga melihat tentang tata kelola perusahaan sebagai faktor yang diprediksi menjadi pemicu praktik konservatisme akuntansi. Beberapa faktor tersebut antara lain kepemilikan institusional (Kung et al., 2008; Salehi \& Sehat, 2018), mekanisme corporate governance (Marzuki et al., 2016; Mohammed et al., 2017; Nasr \& Ntim, 2018), struktur modal (Salama \& Putnam, 2015), auditor tenure (Rickett et al., 2016), auditor independen (Crockett \& Ali, 2015), komposisi dewan komisaris (Enache \& García-Meca, 2018), internal control (Ji, X. Lu \& Qu, 2016), struktur kepemilikan (Xu et al., 2012; Majeed et al., 2017; (Manawadu et al., 2019), serta kompensasi eksekutif (Zhang et al., 2019; (Li et al., 2020).

Faktor lain yang dilihat adalah aktivitas pengungkapan laporan keuangan, seperti pengungkapan tanggung jawab sosial perusahaan (Cheng \& Kung, 2016), adobsi IFRS (Guermazi \& Khamoussi, 2018; Manawadu et al., 2019; Novitasari et al., 2020), aset dan ekuitas (Xie et al., 2012), serta asimetri informasi (Isniawati et al., 2016). Konservatisme juga diteliti dalam hubungannya dengan ketidakpastian lingkungan bisnis (Hejranijamil et al., 2020). Penelitian lain melihat konservatisme akuntansi dilihat pada faktor prilaku biaya (Fourati \& Ghorbel, 2020).

Namun demikian, beberapa faktor tersebut merupakan faktor-faktor umum yang telah sering menjadi isu dalam penelitian akuntansi. Kinerja keuangan, tata kelola, struktur kepemilikan dan modal, serta masalah pengungkapan laporan keuangan telah menjadi determinasi umum untuk membuktikan praktik dan keputusan akuntansi. Sebaliknya, faktor budaya dan etnisitas masih menjadi faktor yang jarang dilihat dalam dalam penelitian akutansi keuangan khususnya tentang konservatisme akuntansi. Sejauh ini, belum satu penelitian pun yang melihat praktik konservatisme akuntansi di Indonesia yang dipicu oleh nilai-nilai budaya etnisitas pejabat yang berwenang dalam aktivitas pelaporan keuangan perusahaan.

Untuk itu, memasukan faktor etnisitas dan nilai-nilai budaya adalah peluang besar untuk memperkaya model penelitain akuntansi keuangan khususnya dalam konteks konservatisme akuntansi. Hal ini didasaran pada (Zeghal \& Lahmar, 2018) yang menjelaskan bahwa budaya merupakan salah satu faktor signifikan yang dapat menjelaskan perbedaan implementasi akuntansi. Pada pandangan yang lain, (Yunos et al., 2012) menjelaskan bahwa budaya etnisitas secara langsung dapat mempengaruhi konservatisme yang pada akhirnya akan mempengaruhi pengukuran informasi keuangan. Nilainilai budaya etnisitas ini akan mempengaruhi konservatisme akuntansi perusahaan melalui komitmen manajemen dan pihak internal yang bersinggungan dengan aktivitas pelaporan informasi keuangan perusahaan (Ongki \& Pangestu, 2018).

\section{TINJAUAN TEORITIS}

\section{Teori kontingensi}

Teori kontingensi merupakan sebuah teori yang mendasari pendekatan dalam studi perilaku organisasi yang menjelaskan bagaimana faktor-faktor kontinjen seperti teknologi, budaya, dan lingkungan perusahaan dapat membawa dampak pada desian dan fungsi dalam sebuah organisasi (Islam \& Hu, 2012). Sebelumnya, (Drazin \& Van de Ven, 1985) menjelaskan bahwa pusat dari teori kontigensi adalah menjelaskan proposisi struktur dan proses organisasi harus dapat dijelaskan oleh 
suatu konteks yang salah satunya berhubungan dengan karakteristik budaya. (Otley, 1980) menyatakan bahwa teori kontingensi harus mengidentifikasi aspekaspek spesifik dari sistem akuntansi yang berhubungan dengan keadaan tertentu yang salah satunya berhubugan dengan aspek budaya. Perbedaan etnisitas dalam konteks nilai-nilai budaya dapat memberikan dampak pada perilaku bisnis seseorang (Koning, 2007). Pilihan pada pandangan konservatif merupakan suatu bentuk prilaku bisnis. Oleh sebab itu, teori kontingensi akan menjadi teori dasar yang akan melandasi penelitian hubungan etnisitas dan konservatisme akuntansi ini.

\section{Konservatisme Akuntansi}

Konservatisme adalah konvensi penting dalam praktik pelaporan keuangan yang menyiratkan prinsip kehati-hatian dalam pengakuan dan pengukuran pendapatan dan aset (Givoly \& Hayn, 2000). Konservatisme akuntansi merupakan prinsip dasar yang selalu mempengaruhi praktik akuntansi dan laporan keuangan (Zeghal \& Lahmar, 2018). Konservatisme akuntansi merupakan prinsip dasar yang selalu mempengaruhi praktik akuntansi dan laporan keuangan (Zhong \& Li, 2016). Praktik konservatisme akuntansi juga dapat digambarkan sebagai tindakan asimetri dalam permintaan verifikasi terhadap laba dan rugi. Oleh sebab itu konservatisme akuntansi akan semakin tinggi mengikuti besarnya perbedaan tingkat verifikasi yang diminta terhadap laba daripada rugi. Masalahnya adalah, konservatisme akuntansi menyiratkan kemungkinan terjadinya kesalahan pengukuran yang cenderung mengesampingkan pendapatan dan aset bersih (Zhu \& Xia, 2011).

Hal yang lain dijelaskan oleh (Zhang et al., 2019) bahwa adopsi konservatisme akuntansi memungkinkan manajemen perusahaan untuk memperoleh kompensasi eksekutif yang linear dengan kinerja perusahaan. Hal ini karena, konservatisme akuntansi dapat membatasi aktivitas manajemen laba dan mengurangi permasalahan yang disebabkan oleh data kinerja akuntansi. Berdasarkan pemikiran tersbut, konservatisme akuntansi juga dianggap sebagai pengganti tata kelola perusahaan seperti halnya investor institusi atau dewan pengawas direksi yang juga dapat meningkatkan sensitivitas dalam pembayaran kompensasi kineja manjemen (Zhang et al., 2019).

Pemikiran dasar dari prinsip konservatisme akuntansi adalah untuk mengurangi risiko dan penggunaan optimisme yang berlebihan manajemen dan pemilik perusahaan terhadap kinerja keuangan perusahaan (Sulastri \& Anna, 2018). Namun demikian, para pengkritik menyatakan bahwa konsep konservatisme akuntansi dapat menyebabkan laporan keuangan menjadi bias dan akan berdampak pada kualitas laba yang dihasilkan menjadi lebih berkurang atau rendah (Deslatu \& Susanto, 2010). Secara ideal, praktik konservatisme normal yang ditentukan oleh keadaan ekonomi perusahaan sering tidak berjalan, sebaliknya, praktik konservatisme akrual yang menyimpang dari konservatisme normal justru sering dilakukan manajemen untuk kepentingan yang tidak sejalan dengan perusahaan (Zhong \& Li, 2016).

Perilaku konservatisme dalam akuntansi sering kali muncul karena didorong oleh perilaku oportunistik manajemen (Xie et al., 2012). Hal ini didukung oleh penjelasan (Li et al., 2020) bahwa banyak praktik konservatisme akuntansi yang dilakuakan oleh para CEO perusahan lebih didasarkan oleh tawar menawar untuk menetukan opsi kompensasi manajemen.

Namun demikian, konservatisme akuntansi juga lebih didasatkan pada keberanian dalam mengabil risiko bisnis. Hal ini seperti dijelaskan oleh (Hejranijamil et al., 2020) bahwa alasan utama manajemen untuk memilih atau tidaknya metode konservatif dalam praktik akuntansi akan tergantung pada persepsi apakah perusahaan berada pada tingkat stabilitas pertumbuhan usaha yang baik. Pencapaian 
pertumbuhan yang stabil menunjukkan risiko perusahaan berada pada tingkat yang lebih rendah dan sebaliknya jika pertumbuhan usaha terganggu maka perusahaan berada pada tingkat risiko yang tinggi.

Bagi para pihak yang cenderung memilih prinsip konservatif, konservatisme akuntansi dianggap akan memberikan fasilitas dalam praktik tata kelola perusahaan yang dampaknya adalah meningkat kinerja investasi dan mengurangi risiko investasi (Hejranijamil et al., 2020). Hal ini juga didukung oleh pendapat bahwa konservatisme dianggap sebagai reaksi bijaksana dalam menghadapi ketidakpastian yang terjadi dalam lingkungan bisnis khusunya pada pasar yang kompetitif (Zubaidah \& Nasrizal, 2019).

Namun disisi yang lain, konservatisme akuntansi justru akan membatasi keberanian para eksekutif perusahaan untuk melakukan investasi berisiko, dengan kata lain, konservatisme akuntansi justru akan mengurangi keberanian para eksekutif perusahaan dalam mengambil risiko bisnis (Kravet, 2014). Hal ini menujukkan bahwa konservatisme berhubungan dengan keberanian dalam mengabil risiko. Hal ini beralasan karena konservatisme akuntansi lebih cenderung memicu untuk usaha menghidari risiko dan lebih memilih untuk mengambil tindakan protektif (Zhong \& Li, 2016).

\section{Etnisitas}

Etnisitas dengan nilai-nilai budaya yang berbeda-beda akan berhubungan dengan perilaku pengelolaan bisnis (Koning, 2007). Budaya menyediakan solusi fungsional untuk masalah interaksi sosial dalam komunitas dan masyarakat (Brett, 2017). Perbedaan nilai-nilai budaya suatu kelompok etnis akan mempengaruhi perilaku seseorang (Kania, 2010). Perbedaan nilai-nilai budaya suatu kelompok etnis juga akan berperan dalam membentuk kebiasaan-kebiasaan dalam praktik bisnis mereka (Musianto, 2003).
Pengusaha Tionghoa juga dikenal sebagai pengusaha yang lebih memilihi untuk melakukan pemberdayaan partisipatif dan peran serta orang lain, serta mengedepankan rasa tanggung jawab (Pontjharyo, 2011). Pada sisi lain, (Mangundjaya, 2013) mengidentifikasi bahwa secara umum etinis Pribumi Indonesia cenderung memiliki karakteristik yang menekankan pada kondisi stabil, jangka pendek dan berfikir konservatif.

Untuk itu, budaya sebagai aspek informal organsasional seringkali menjadi faktor penting yang harus diperhatikan dalam penentuan keputusan strategis perusahaan (Setiawan et al., 2019b). Kebiasaan dan budaya suatu kelompok etnisitas akan sangat mungkin mempengaruhi tata kelola bisnis mereka (Setiawan et al., 2019a). Hal ini sangat beralasan karena, nilai-nilai budaya etnisitas akan menjadi satu faktor yang sangat fundamental dan penting yang harus diperhatikan seseorang dalam menjalankan aktivitas bisnis (Kania, 2010). Oleh karena itu, nilai-nilai budaya yang dipegang oleh sekelompok etnisitas akan memberikan pengaruh dalam pengelolaan organisasi bisnis (Mangundjaya, 2013).

\section{Pengaruh Etnisitas Pada Konservatisme} Akuntansi

Nilai-nilai budaya etnisitas dapat mendorong manajer atau akuntan untuk menggunakan kebijaksanaan dalam membuat estimasi akuntansi sehingga, kelompok etnis dapat mempengaruhi keputusan untuk mengadopsi prinsip konservatisme akuntansi (Yunos et al., 2012). Penjelasan dan temuan tersebut relevan dengan pendapat (Kung et al., 2011) bahwa sistem dan budaya lingkungan dapat berperan untuk memengaruhi aktivitas pelaporan keuangan. Hal ini didukung oleh temuan penelitian (Setiawan et al., 2019a) yang menyimpulkan bahwa kelompok etnisitas pemilik hotel yang berbeda akan menerapkan praktik akuntansi yang juga berbeda. (Slater et al., 2007) menyimpulkan bahwa lingkungan dan 
budaya akan menjadi faktor penting bagi manajemen untuk mempertimbangkan kebijakan dan keputusan bisnis.

Temuan yang sama dijelaskan (Bhaskaran \& Sukumaran, 2007) bahwa keputusan operasi bisnis akan dipengaruhi oleh perbedaan nilai budaya etnisitas yang dimiliki oleh pemilik dan manajer perusahaan. Hal ini didukung oleh (Blackburn et al., 2013) bahwa karakteristik pemilik usaha dapat berdampak pada strategi dan rencana bisnis yang dijalankan. Akhirnya beberapa hasil temuan tersebut juga didukung oleh temuan (Zeghal \& Lahmar, 2018) bahwa variabel budaya mempunyai peran dalam tingginya tingkat konservatisme akuntansi perusahan, dan nilai-nilai budaya yang dianut para pengusaha pada akhirnya akan mempengaruhi pilihan strategi bisnis perusahaan (Setiawan et al., 2020). Berdasarkan beberapa penjelasan dan temuan tersebut maka, hipotesis yang akan dibuktikan dalam penelitian ini adalah;

Ha : Perbedaan kelompok etnisitas pejabat yang berwenang dalam pelaporan keuangan perusahaan akan berpengaruh pada tingkat konservatisme akuntansi di suatu perusahaan.

\section{METODE PENELITIAN}

Populasi penelitian adalah perusahaan sektor manufaktur yang terdaftar di Bursa Efek Indonesia (BEI) untuk tahun 2019. Sampel penelitian ditentukan dengan menggunakan metode purposive sampling dengan kriteria sebagai berikut:

1. Perusahaan termasuk dalam sektor manufaktur yang terdaftar di Bursa Efek Indonesia pada tahun 2019.

2. Perusahaan tersebut mempublikasikan laporan keuangan tahunan selama periode 2019 yang berisi data serta informasi yang lengkap sehingga dapat digunakan dalam penelitian ini serta laporan keuangan tersebut telah diaudit.

3. Laporan keuangan disajikan dalam mata uang rupiah. Hal ini dikarenakan agar tidak terjadi kesalahan dalam mentranslasikan angka-angka dalam laporan keuangan yang tidak menggunakan satuan mata uang rupiah akibat adanya selisih kurs.

4. Perusahaan manufaktur pada tahun penelitian 2019 tidak mengalami delesting.

5. Perusahaan diidentifikasi melakukan konservatisme akuntansi pada tahun 2019 dengan ditunjukkan dari nilai total akrual yang positif.

Konservatisme didefinisikan sebagai prinsip kehati-hatian dalam mengakui aset dan laba, dan segera mengakui beban dan kewajiban dengan alasan bahwa aktivitas bisnis dan ekonomi dilingkupi oleh ketidakpastian (Kurniawan \& Suryaningsih, 2018). Nilai konservatisme akuntansi dihitung menggunakan model (Givoly \& Hayn, 2000) sebagai berikut:

CONACC $=\frac{(N I O-D E P)-C F O}{T A} x(-1)$

Dimana:

CONACC : Tingkat Konservatisme Akuntansi

NIO : Laba Bersih pada tahun berjalan

DEP : Penyusutan Aset Tetap pada tahun berjalan

CFO : Arus Kas Operasional

TA : Total Aset

Etnisitas didefinisikan sebagai identitas kolektif yang dapat menjadi dimensi awal dan penting dari identifikasi diri (Koning, 2007). Pada penelitian ini, kelompok etnistias digunakan untuk mengidentifikasi etnis pejabat yang berwenang dalam memberikan otorisasi dalam pemublikasian laporan keuangan perusahaan. Otorisasi tercermin dari tandatangan yang dibubuhkan pada laporan keuangan yang dipublikasikan. Pengelompokkan etnisitas dalam penelitian ini dikategorikan dalam (1) Pribumi dan (2) Tionghoa (Setiawan et al., 2019a) 
HASIL PENELITIAN

Berikut disajikan hasil penelitian yang dimulai dari penjelasan kriteria dan hasil pengambilan sampel perusahaan seperti yang ditunjukan pada tabel 1 berikut

Tabel 1. Kriteria dan Hasil Pengambilan Sampel Perusahaan

\begin{tabular}{llc}
\hline No & Kriteria Sampel & Jumlah Perusahaan \\
\hline 1. & $\begin{array}{l}\text { Perusahaan termasuk dalam sektor manufaktur yang terdaftar di } \\
\text { Bursa Efek Indonesia Periode 2019. }\end{array}$ & 177 \\
2. & $\begin{array}{l}\text { Perusahaan tidak mengungkapkan data keuangan yang dibutuhkan } \\
\text { dalam penelitian secara lengkap selama periode 2019. }\end{array}$ & $(62)$ \\
3. & $\begin{array}{l}\text { Publikasi laporan keuangan perusahaan pada tahun 2019 di Bursa } \\
\text { Efek Indonesia yang tidak ditemukan. }\end{array}$ & $(6)$ \\
4. & $\begin{array}{l}\text { Laporan keuangan perusahaan yang tidak disajikan dalam mata } \\
\text { uang rupiah selama periode 2019 }\end{array}$ & $(16)$ \\
5. & Perusahaan tidak teridentifikasi melakukan konservatisme akuntansi \\
\hline
\end{tabular}

\section{Statistik Deskriptif}

Tabel 2. Statistik Deskriptif Konservatisme Akuntansi

\begin{tabular}{lcccc}
\hline & Minimum & Maksimum & Rata-tata & SD \\
\hline Konservatisme akuntansi & 0,0204 & 1,4069 & 0,3105 & 0,2502 \\
\hline
\end{tabular}

Sumber: data diolah

(Andreas et al., 2017) menjelaskan bahwa perusahaan memiliki total akrual yang positif adalah perusahaan yang menerapkan konservatisme akuntansi sedangkan perusahaan yang memiliki akrual negatif merupakan perusahaan yang menerapkan akuntansi optimis. Tabel 2 menunjukkan indentifikasi perilaku

Tabel 3. Statistik Deskriptif Etnisitas

\begin{tabular}{lcc}
\hline Etnisitas & Jumlah & $\begin{array}{c}\text { Persentas } \\
\text { e }\end{array}$ \\
\hline Tionghoa & 38 & 53,5 \\
Pribumi & 33 & 46,5 \\
\hline
\end{tabular}

Sumber: data diolah

Tabel 3 menunjukan etnisitas pejabat yang berwenang untuk mengotorisasi pemublikasian laporan keuangan perusahaan. Pejabat tersebut akan membubuhkan tandatangan sebagai otorisasi dan pengesahan laporan konservatisme akuntansi pada pelaporan keuangan perusahaan. Nilai konservatisme terendah berada pada angka 0,0204 sedangankan nilai konservatisme akuntansi tertinggi berada pada angka 1,4069 dengan nilai rata-rata konservatisme akuntansi berada pada angka 0,3105 .

keuangan. Berdasarkan identifikasi dalam pengumpulan data, 38 perusahaan $(53,5 \%)$ memiliki pejabat yang berwenang dalam mengotorisasi laporan keuangan yang dipublikasikan merupakan pejabat beretnis Tionghoa, sisanya 33 perusahaan $(46,5 \%)$ adalah pejabat dengan kelompok etnis Pribumi.

\section{Pengujian Hipotesisi}

Hasil Uji Normalitas Data

Tabel 4. Hasil Uji Normalitas

\begin{tabular}{ccc}
\hline Variabel & KS (Asym.sig) & Keputusan \\
\hline Konservatisme akuntansi & $1,058(0,213)$ & Berdistribusi Normal \\
\hline
\end{tabular}

Sumber: data diolah 
Pengujian normalitas hanya dilakukan untuk variabel konservatisme akuntansi saja. Berdasarkan Tabel 4 dapat dilihat bahwa nilai signifikansi KS $>$ dari 0,05 .
Hal ini dapat disimpulkan bahwa data konservatisme akuntansi berdistribusi Normal.

Tabel 5. Hasil Uji Independent Sample t Test

\begin{tabular}{ccc}
\hline Pengujian & Nilai p-value & Keputusan \\
\hline Levene test & 0,065 & Varian Populasi Sampel sama \\
\hline Equal Variance assumed & $0,039^{* *}$ & Hipotesis Diterima \\
\hline KA-Tionghoa & mean:0,2516 (std defiasi: 0,1821 ) & \multirow{2}{*}{ KA Tionghoa $<$ KA Pribumi } \\
KA-Pribumi & mean:0,3783 (std deviasi: 0,3784$)$ & \\
\hline
\end{tabular}

**signifikan pada 5\%

Sumber: data diolah

Hipotesisi penelitian diuji menggunakan independent sample $t$ test. Tabel 5 menunjukkan hasil pengujian tersebut. Berdasarkan nilai Levene test, nilai $p$-value $F$ hitung berada pada angka 0,065. Angka tersebut menunjukkan bahwa signifikansi Levene test berada diatas nilai $\alpha 0,05$, sehingga dapat disimpulkan bahwa varian populasi sampel kedua kategori penelitian (konservatisme akuntansi kelompok etnisitas Tionghoa dan Pribumi) adalah sama. Atas kondisi tersebut maka pengujian perbedaan antara sampel kelompok konservatisme akuntansi etnis Tionghoa dan Pribumi menggunakan nilai uji beda equal variance assumed.Hasil uji beda pada egual variance assumed (Tabel 5) menunjukkan nilai $p$-value $\mathrm{t}$ hitung 0,039. Angka tersebut menunjukkan bahwa signifikansi $t$ hitung berada dibawah nilai $\alpha 0,05$, sehingga dapat disimpulkan bahwa terdapat perbedaan antara konservatisme akuntansi kelompok etnisitas Tionghoa dan Pribumi.

Akhirnya, penelitian dapat melihat perbandingan nilai rata-rata (mean) antara konservatisme akuntansi kelompok etnis Tionghoa dan Pribumi. Berdasarkan Tabel 5 nampak bahwa nilai rata-rata KATionghoa berada pada angka 0,2516, sementara nilai rata-rata KA-Pribumi berada pada angka 0,3783. Hal ini menunjukkan bahwa nilai rata-rata konservatisme akuntansi etnis Tionghoa lebih rendah dibandingkan nilai rata-rata konservatisme akuntansi etnis Pribumi, sehingga dapat disimpulkan bahwa, hipotetis penelitian yang menyatakan terdapat pengaruh etnisitas terhadap perilaku konservatisme akuntansi dapat didukung.

\section{PEMBAHASAN}

Hasil penelitian ini berhasil mendukung hipotesis yang menyatakan perbedaan kelompok etnisitas pejabat yang berwenang dalam pelaporan keuangan perusahaan akan berpengaruh pada tingkat konservatisme akuntansi di suatu perusahaan. Temuan ini relevan dengan beberapa kesimpulan penelitian yang dilakukan oleh (Yunos et al., 2012; Kung et al., 2011; Setiawan et al., 2019a) bahwa kelompok etnisitas manajemen atau pemilik usaha dapat membawa pengaruh tehadap kebijakan bisnis dan akuntansi yang mereka pilih. Nilai-nilai budaya yang melekat pada suatu kelompok etnisitas akan menjadi kebiasaan dan identitas dalam kehidupan sehari-hari. Oleh sebab itu menjadi beralasan jika budaya akan menjadi faktor penting bagi manajemen dalam membuat pertimbangan kebijakan bisnis mereka (Slater et al., 2007).

Temuan empiris yang menunjukkan bahwa etnis Tionghoa memiliki tingkat konservatisme akuntansi yang lebih rendah dari pada kelompok etnis Pribumi juga semakin menguatkan literatur (Musianto, 2003) yang menggambarkan bahwa etnis 
Tionghoa dikenal sebagai kelompok pengusaha yang memiliki sifat kreatif dan inovatif dan berani ambil risiko. Pada sisi yang lain temuan ini juga mendukung temuan (Mangundjaya, mengidentifikasi etinis Pribumi Indonesia sebagai kelompok etnis yang cenderung memiliki karakteristik untuk menyukai kondisi stabil, jangka pendek dan lebih berfikir konservatif. Temuan ini semakin menguatkan penjelasan (Setiawan et al., 2019a) bahwa kebiasaan dan budaya suatu kelompok etnisitas akan mempengaruhi gaya tata kelola bisnis mereka.

Seperti telah dijelaskan pada bagian sebelumnya, prilaku konservatif akan berhubungan dengan keberanian dalam mengabil risiko. Hal ini seperti dijelaskan oleh (Zhong \& Li, 2016) bahwa manajemen yang berupaya mengurangi risiko dalam keputusan investasi akan mengambil pilihan konservatif dalam menerapkan praktik akuntansi mereka. Hal sama, sebelumnya telah dijelaskan oleh (Kravet, 2014) bahwa konservatisme akuntansi akan banyak dipilih oleh para eksekutif perusahaan yang tidak berani mengabil keputusan investasi yang memiliki risiko lebih tinggi.

Perilaku konservatisme dalam akuntansi yang sering kali muncul karena didorong oleh perilaku oportunistik dari manajemen juga menunjukkan adanya kencederungan bahwa manajemen ingin lebih mendahulukan kepentingan mereka sendiri. Terlebih beberapa penelitian terdahulu juga membuktikan bahwa perilaku oportunistik para eksekutif yang didasarkan para prinsip konservatisme banyak ditujukan untuk kepentingan insentif bagi mereka (Zhang et al., 2019; Li et al., 2020). Hal ini menjadi menarik saat hasil penelitian ini dapat menemukan bukti bahwa pebedaan etnisitas manajemen membawa dampak pada perbedaaan pada pilihan prinsip konservatisme mereka.

Kelompok etnis Pribumi dan Tionghoa dalam menerapkan prinsip konservatisme dalam praktik akuntansi mereka menunjukkan adanya pengaruh nilai-nilai budaya yang mereka warisi dari para leluhur. Penelitian sebelumnya, (Setiawan et al., 2020) telah membuktikan bahwa perbedaan nilai budaya berdampak pada pilihan strategi. Pilihan untuk menerapkan prinsip konservatif atau sebaliknya sebenarnya juga merupakan bentuk pilihan strategi. pada beberapa literatur sebelumnya telah banyak membahas bagaimana nilai-nilai budaya etnis Tionghoa memiliki perbedaan dengan nilia-nilia budaya etnis Pribumi. Nilai-nilai tersebut sudah dibuktikan dalam beberapa literatur juga memberikan bukti adanya dampak pada tata kelola bisnis yang dijalankan.

Etnis Tionghoa yang memiliki ciri berani ambil risiko, sementara etnis Pribumi lebim memilih untuk menerapkan pilihan kondisi stabil sudah cukup memberikan alasan mengapa pejabat dengan etnis Tionghoa lebih rendah dalam menerapkan prinsip konservatisme dibandingan dengan pejabat yeng beretnis Pribumi. Sekali lagi, temuan ini semkin menguatakan beberapa temuan sebelumnya yang telah melihat perbedaan nilai budaya dalam kelompok etnisitas dapat membawa dampak pada perilaku bisnis seseorang (Koning, 2007; Setiawan et al., 2019a; Setiawan et al., 2020).

Akhirnya, temuan penelitian ini juga semakin memperjelas temuan (Bhaskaran \& Sukumaran, 2007) perbedaan nilai budaya etnisitas yang dimiliki oleh pemilik atau manajemen perusahaan akan mempengaruhi keputusan bisnis mereka. Karakteristik pengusaha yang cenderung berfikir untuk mendapatkan kondisi stabil akan cenderung penuh dengan kehatihatian dalam membuat keputusan. Sebaliknya, pengusaha yang memiliki prinsip kuat untuk berani ambil risiko akan memilki sifat konservatisme yang lebih rendah. Untuk itu, temuan ini juga relevan untuk menguatkan (Zeghal \& Lahmar, 2018) bahwa budaya etnisias mempunyai 
peran dalam terbentunya tingkat konservatisme akuntansi yang dianut oleh seorang manajemen dalam melaporkan pelaporan keuangannya kepada publik.

\section{KESIMPULAN DAN SARAN \\ Kesimpulan}

Berdasarkan temuan dari penelitian ini maka dapat disimpulkan bahwa perbedaan kelompok etnisitas pejabat yang berwenang dalam pemublikasian laporan keuangan perusahaan kepada publik akan memiliki pengaruh pada tingkat konservatisme akuntansi yang mereka anut. Etnis Pribumi dengan karakteristik umum sebagai etnis yang lebih mengedepankan sifat stabil dalam berusaha cenderung memiliki sifat konservatisme yang lebih tinggi dibandingkan dengan kelompok etnis Tionghoa yang cenderung lebih berani ambil risiko pada setiap keputusan mereka. Sifat dasar karakteristik nilai budaya yang mengedepankan pilihan stabil adalah prinsip yang mengedepakan pilihan aman dan nyaman. Oleh sebab itu sangat beralasan jika karakteristik nilai budaya seperti ini akan lebih memilih prinsip yang lebih konservatif. Sebaliknya nilai-nilai budaya yang mengedepankan keberanian untuk mengambil risiko, adalah nilai-nilai yang mengedepankan prinsip berfikir jangka panjang dan memiliki keyakinan yang kuat untuk mampu mengantisipasi potensi maslah yang mungkin akan terjadi. Oleh sebab itu, hal ini juga menjadi beralasan saat kelompok orang yang memiliki prinsip demikian akan cenderung menerapkan prinsip koservatisme yang lebih longgar. Hasil penelitian ini berhasil mengkonfirmasi dan memberi dukungan pada beberapa temuan dan litertur tentang konteks perbedaan nilai-nilai budaya etnisitas yang ada sebelumnya.

Oleh sebab itu, implikasi penting dari hasil penelitian ini adalah para pejabat yang berwenang dalam pemublikasian laporan keuangan perusahaan harus dapat mengendalikan prinsip konservatime mereka. Prinsip konservatisme yang berlebihan akan cenderung menghasilkan informasi keuangan yang tidak akurat. Namun demikan prinsip optimisme yang terlalu tinggi juga dapat berpotensi memberikan kerugian dimasa datang. Keberanian dalam mengambil risiko harus diimbangi dengan perhitungan yang akurat. Sebaliknya prinsip kehati-hatian harus dimbangi dengan penyajian informasi yang fair.

\section{Saran}

Namun demikian, penelitian ini masih memiliki beberapa keterbatasan. Pada penelitian ini, identifikasi etnisitas hanya dilakukan dengan mengidentifikasi berdasarkan nama pejabat dan mengumpulakan data gambar wajah yang bersangkutan. Hal ini memiliki risiko bias dalam menentukan kategori etnis sesorang. Selain itu, penelitian hanya difokuskan pada bidang industri manufaktur. Penelitian juga hanya dibatasi pada dua kelompok etnis, yaitu etnis Pribumi dan etnis Tionghoa.

Untuk itu, penelitian selanjutnya dapat mempertimbangkan metode lain untuk mengidentifikasi etnis sesorang misalnya dengan menelusur informasi yang tertera di biodata orang tersebut. Penelitian kedepan juga disarankan untuk melihat semua sektor industri. Hal ini karena, setiap sektor industri akan memiliki kompleksitas dan risiko bisnis yang berbeda-beda. Kompleksitas dan risiko yang berbeda berkemungkinan akan mempengaruhi tingkat konservatisme yang berbeda dari manajemen.

Pada hal yang lain, kelompok etnisitas pribumi juga memiliki variasi yang heterogen. Kelompok etnistas yang heterogen akan sangat mungkin memiliki nilai-nilai budaya yang spesifik. Jika kedua saran tersebut dapat dilakukan dalam penelitian mendatang, hasil penelitan mendatang diharapkan dapat memberikan hasil temuan yang lebih lengkap dalam menjawab kompleksitas perbedaan etnisitas dalam pengelolan 
bisnis khususnya dalam perilaku konservatisme pengusaha di Indonesia.

\section{DAFTAR PUSTAKA}

Abdurrahman, M. A., \& Ermawati, W. J. (2018). Pengaruh leverage, financial distress dan profitabilitas terhadap konservatisme akuntansi pada perusahaan pertambangan di Indonesia tahun 2013 - 2017. Jurnal Manajemen Dan Organisasi, 9(3), $164-173$.

Andreas, H. H., Ardeni, A., \& Nugroho, P. I. (2017). Konservatisme akuntansi di Indonesia. Jurnal Ekonomi Dan Bisnis, 20(1), 1 - 23.

Bhaskaran, S., \& Sukumaran, N. (2007). National culture, business cuture and management practices: Consequential relationship? Cross Cultural Management: An International Journal, 14(1), $54-67$.

Blackburn, R. A., Hart, M., \& Wainwright, T. (2013). Small business performance: business, strategy, and owner - manager characteristics. Journal of Small Business and Enteeprise Development, 20(1), 8 27.

Brett, J. M. (2017). Culture and negotiation strategy. Journal of Business \& Industrial Marketing, 32(4), $587-590$.

Chan, A. L. C., Lin, S. W. J., \& Strong, N. (2009). Accounting conservatism and the cost of equity capital: UK evidence. Managerial Finance, 35(4), 325-345.

Cheng, C. L., \& Kung, F. H. (2016). The effects of mandatory corporate social responsibility policy on accounting conservatism. Review of Accounting and Finance, 15(1), 2 - 20.

Crockett, M., \& Ali, M. J. (2015). Auditor independence and accounting conservatism. International Journal of Accounting \& Information Management, 23(1), 80 - 104.

Deslatu, S., \& Susanto, Y. K. (2010). Pengaruh kepemilikan managerial, debt covenant, litigation, tax and political costs dan kesempatan bertumbuh terhadap konservatisma akuntansi. Ekuitas, 14(2), 137 - 151.

Drazin, R., \& Van de Ven, A. . (1985). Alternative forms of fit in contingency theory. Administrative Science Quarterly, 30(40), 514-539.

Enache, L., \& García-Meca, E. (2018). Board composition and accounting conservatism: The role of business experts, support specialist and community influentials. Australian Accounting Review, 29(1), 1 - 14.

Fourati, Y. M., \& Ghorbel, R. C. (2020). Sticky cost behavior and it simplication on accounting conservatism: a cross-country study. Journal of Financial Reporting and Accounting, 18(1), 169 - 197.

Givoly, D., \& Hayn, C. (2000). The changing time-series properties of earnings, cash flows and accruals: Has financial reporting become more conservative? Journal of Accounting and Economics, 29(3), 287 - 320.

Guermazi, W., \& Khamoussi, H. (2018). Mandatory IFRS adoption in Europe: Effect on the conservative financial reporting. Journal of Financial Reporting and Accounting, 16(4), 543 $-563$.

Hejranijamil, M., Hejranijamil, A., \& Shekarkhah, J. (2020). No Title. Accounting Conservatism and Uncertainty in Business Environments; Using Financial Data of Listed Companies in the Tehran Stock Exchange, 5(2), 179 - 194.

Islam, J., \& Hu, H. (2012). A review of literature on contingency theory in managerial accounting. African Journal of Business Management, 6(15), $5159-5164$.

Isniawati, A., Rahmawati, \& Budiatmanto, A. (2016). Pengaruh asimetri informasi dan analyst coverage terhadap konservatisme akuntansi. Jurnal Akuntansi \& Auditing 
Indonesia, 20(2), 99 - 109.

Ji, X. Lu, W., \& Qu, W. (2016). Internal control weakness and accounting conservatism in China. Managerial Auditing Journal, 31(6/7), 688 - 726.

Kania, S. M. (2010). The role of cultural differences in forming a business strategy. Journal of Business and Management, 16(4), 21 - 24.

Koning, J. (2007). Chineseness and Chinese Indonesian business practices: A generational and discursive enquiry. East Asia, 24(2), $129-152$.

Kravet, T. . (2014). Accounting conservatism and managerial risktaking: Corporate acquisitions. Journal of Accounting and Economics, 57(2/3), 218 - 240.

Kung, F., James, K., \& Cheng, C. (2011). Overseas listing and accounting conservatism: Evidence from Chinese $\mathrm{H}$-share companies. Asian Review of Accounting, 19(3), 266-278.

Kung, F., Ting, C., \& James, K. (2008). Accounting conservatism in Greater China: The influence of institutions and incentives. Asian Review of Accounting, 16(2), $134-148$.

Kurniawan, C., \& Suryaningsih, R. (2018). Pengaruh konservatisme akuntansi, debt to total assets ratio, likuiditas, profitabilitas, dan ukuran perusahaan terhadap kualitas laba. EQUITY: Jurnal Ekonomi, Manajemen, Akuntansi, 21(2), 163 - 180.

Li, H., Henry, D., \& Wu, X. (2020). The effects of accounting conservatism on executive compensation. International Journal of Managerial Finance, 16(3), 393 - 411.

Majeed, M. A., Zhang, X., \& Wang, Z. (2017). Product market competition, regulatory changes, ownership structure and accounting conservatism. Chinese Management Studies, 11(4), $658-688$.

Manawadu, I., Che Azmi, A., \& Mohamed, A. (2019). Moderating effect of IFRS adoption on FDI and conditional accounting conservatism in South Asia. Journal of Accounting in Emerging Economies, 9(1), 51 74.

Mangundjaya, W. L. H. (2013). Is there culture change in the national cultures of Indonesia. In: Yoshihisa Kashima, Emmiko S. Kashima dan Ruth Beatson (Eds.). Steering the Cultural Dynamic. Selected Paper from the 2010 Congress of the International Association for Cross-Cultural Psychology, 59- 68.

Marzuki, M. M., Wahab, A. E. A., \& Haron, H. (2016). Corporate governance and earnings conservatism in Malaysia. Accounting Research Journal, 29(4), 391-412.

Mohammed, N. F., Ahmed, K., \& Ji, X. D. (2017). Accounting conservatism, corporate governance and political connections. Asian Review of Accounting, 25(2), 288-318.

Musianto, L. S. (2003). Peran orang Tionghoa dalam perdagangan dan hidup perekonomian dalam masyarakat (Studikepustakaan dan studi kasus tentang interkasi etnik Tionghoa dan Pribumi di bidang perekonomian di Surabaya). Jurnal Manajemen \& Kewirausahaan, 5(2), $193-206$.

Nasr, M. A., \& Ntim, C. G. (2018). Corporate governance mechanisms and accounting conservatism: evidence from Egypt. Corporate Governance: The International Journal of Business in Society, 18(3), 386-407.

Novitasari, Amin, M., \& Hariri. (2020). Pengaruh adopsi IFRS, political cost, dan litigation risk terhadap konservatisme akuntansi (Studi empiris terhadap perusahaan manufaktur yang terdaftar di bursa efek Indonesia periode tahun 20162018). E-JRA, 9(3), 116 - 125.

Ongki, S., \& Pangestu, S. (2018). 
Determinan dan konsekuensi konservatisme akuntansi: mekanisme corporate governance dan manajemen laba. BALANCE, 15(1), 90-112.

Otley, D. (1980). The contingency theory of management accounting: Achievements and prognosis. Accounting Organizations and Society, 5(3), 413-428.

Pontjharyo, W. (2011). The analysis of Chinese character-based on accounting and value implications for Chinese Indonesian business. Asia Pacific Journal of Accounting and Finance, 1(2), 150 - 164.

Rahmadhani, S., \& Nur, A. (2015). Analisa faktor-faktor yang mempengaruhi konservatisme akuntansi. Jurnal Ilmu Manajemen Dan Akuntansi Terapan, 6(1), 120 141.

Rickett, L. K., Maggina, A., \& Alam, P. (2016). Auditor tenure and accounting conservatism: Evidence from Greece. Managerial Auditing Journal, 31(6/7), 538-565.

Salama, F. M., \& Putnam, K. (2015). Accounting conservatism, capital structure, and global diversification. Pacific Accounting Review, 27(1), 119-138.

Salehi, M., \& Sehat, M. (2018). Debt maturity structure, institutional ownership and accounting conservatism: Evidence from Iranian listed companies. Asian Journal of Accounting Research, 4(1), 35 - 51.

Setiawan, A. S., Ony, J. G., \& Permata, V. S. (2020). The effect of cultural values on business strategy choices. Jurnal Manajemen, 24(1), 158 - 173.

Setiawan, A. S., Rahmawati, Djuminah, \& Widagdo, A. K. (2019a). Owner ethnicity and strategic management accounting. Jurnal Akuntansi, 23(2), $160-176$

Setiawan, A. S., Rahmawati, Djuminah, \& Widagdo, A. K. (2019b). Owner power, deliberate strategy formulation, and strategic management acounting. Opción, 35(89), 254-270.

Slater, S., Paliwoda, S., \& Slater, J. (2007). Ethnicity and Decision Making for Internationalization. Management Decision, 45(10), 1622 $-1635$.

Sugiarto, H. V. S., \& Fachrurrozie. (2018). The Determinant of accounting conservatism on manufacturing companies in Indonesia. Accounting Analysis Journal, 7(1), 1 - 9.

Suharni, S., Wildaniyati, A., \& Andreana, D. (2019). Pengaruh jumlah dewan komisaris, leverage, profitabilitas, intensitas modal, cash flow, dan ukuran perusahaan terhadap konservatisme (Studi empiris pada perusahaan manufaktur yang terdaftar di Bursa Efek Indonesia tahun 20122017). EKOMAKS: Jurnal Ilmu Ekonomi, Manajemen, Dan Akuntansi., 8(1), 17 - 24.

Sulastri, S., \& Anna, Y. D. (2018). Pengaruh financial distress dan leverage terhadap konservatisme akuntansi. AKUISISI Jurnal Akuntansi, 14(1), 58 - 68.

Sun, J., \& Liu, G. (2011). The effect of analyst coverage on accounting conservatism. Managerial Finance, 37(1), 5-20.

Susanto, B., \& Ramadhani, T. (2016). Faktor-faktor yang mempengaruhi konservatisme (Studi pada perusahaan manufaktur yang terdaftar di BEI 2010 - 2014). Jurnal Bisnis Dan Ekonomi, 23(2), 142 - 151.

Wijaya, A. L. (2012). Pengukuran konservatisme akuntansi: Sebuah literatur review. ASSET: Jurnal Akuntansi Dan Pendidikan, 1(1), 100 $-105$.

Xie, Y., Zheng, L., \& Lau, H. L. A. (2012). Reporting incentives for accounting conservatism, evidence from asset and equity tunnelling. Pacific Accounting Review, 24(2), 
$138-160$

Xu, X., Wang, X., \& Han, N. (2012). Accounting conservatism, ultimate ownership and investment efficiency. China Finance Review International, 2(1), 53-77.

Yunos, M. R., Ismail, Z., \& Smith, M. (2012). ). Ethnicity and accounting conservatism: Malaysian evidence. Asian Review of Accounting, 20(1), 34-57.

Zeghal, D., \& Lahmar, Z. (2018). The effect of culture on accounting conservatism during adoption of IFRS in the EU. International Journal of Accounting \& Information Management, 25(2), 311-330.

Zhang, X., Gao, S., \& Zeng, Y. (2019). An empirical study of relationships between accounting conservatism and executive compensation-performance sensitivity. International Journal of Accounting \& Information, 27(1), 130 $-150$.

Zhong, Y., \& Li, W. (2016). Accounting conservatism: A literature review. Australian Accounting Review, 27(2), 195-213.

Zhu, S., \& Xia, D. (2011). Accounting conservatism and stock pricing: an analysis based on China's split-stock reform. Nankai Business Review International, 2(1), 23-47.

Zubaidah, Z., \& Nasrizal, N. (2019). The effect of audit tenure, investment opportunity set and accounting conservatism towards earning quality with managerial ownership as moderating variable. International Journal of Economic, Business and Applications, 4(2), 1 - 17. 